\title{
EFFECTS OF RODENTICIDE ON GROWTH OF NESTLING BARN OWL, Tyto alba javanica IN OIL PALM PLANTATIONS
}

\author{
HASBER SALIM*; HAFIDZI MOHD NOOR**; ROSNIDA TAJUDIN*; NOOR HISHAM HAMID;; \\ DZOLKHIFLI OMAR*; AZHAR KASIM ${ }^{\ddagger \ddagger}$ and CIK MOHD RIZUAN ZAINAL ABIDIN ${ }^{\ddagger}$
}

\begin{abstract}
This study investigated the effects of the first generation anti-coagulant rodenticide, chlorophacinone and the second generation rodenticide, bromadiolone on nestling growth of barn owl, Tyto alba javanica in oil palm plantations. Forty-two nestlings were selected from rodenticide-free, chlorophacinone and bromadiolone treated plots. Growth rates of nestlings were measured by taking body weight, culmen length, tarsus length and wing length on a periodic basis. Dead nestlings were collected during daily observations. Autopsies were carried out to determine cause of mortality and internal organ (livers) were harvested for analysis of residue by using high performance liquid chromatography (HPLC). Rodenticide-free plot scored the highest fledging success, i.e. $71.4 \%(n=14)$ at 52 days after hatching. In chlorophacinone treated plot, six out of 14 nestlings or $42.85 \%$ successfully grew to fledging age of 52 days. In bromadiolone treated plot, only five or $35.75 \%(n=14)$ of nestlings survived to fledging age. Three out of nine nestling carcasses found in bromadiolone treated area were collected for the analysis. Of these, two were detected with bromadiolone residue measuring $0.33 \mu g^{-1}$ and $0.41 \mu g^{-1}$ wet weight, respectively. In chlorophacinone treated plot, three out of eight carcasses were collected for analysis. The residue of chlorophacinone detected ranged from $0.18 \mu g^{-1}$ to $0.21 \mu g^{-1}$. Nestlings that survived in the rodenticide-free area showed higher measurements for body weight, tarsus, culmen and wing length compared to bromadiolone and chlorophacinone treated plots.
\end{abstract}

Keywords: barn owl, secondary poisoning, chlorophacinone, bromadiolone.

Date received: 15 May 2015; Sent for revision: 2 June 2015; Received in final form: 17 December 2015; Accepted: 13 January 2016.

\footnotetext{
* School of Biological Sciences,

Universiti Sains Malaysia,

11800 Minden, Pulau Pinang, Malaysia.

** Department of Plant Protection,

Faculty of Agriculture, Universiti Putra Malaysia,

43400 UPM Serdang, Selangor, Malaysia.

E-mail: hafidzi@upm.edu.my

* Crop Protection Division,

Felda Agricultural Services Sdn Bhd, PPP Tun Razak, 27000 Jerantut, Pahang, Malaysia.

\# Department of Animal Science,

Faculty of Agriculture, Universiti Putra Malaysia, 43400 UPM Serdang, Selangor, Malaysia.
}

\section{INTRODUCTION}

Chemical control using anti-coagulant rodenticides integrated with biological control using barn owls, Tyto alba has been adopted since the late 1980s against rat populations in oil palm plantations in Malaysia (Wood and Chung, 2003). However, application of anti-coagulant rodenticides in combination with the natural propagation of barn owls in oil palm plantations has raised concerns of potential secondary poisoning to the latter (Ducket, 1984; Naim et al., 2012). Duckett (1984) reported that anti-coagulants cause a population of 
T. alba to decline. He demonstrated the potentially adverse effects of second generation rodenticides following the introduction of second generation anti-coagulant to control rats in Malaysian oil palm plantations. Within 30 months, a population of 40 T. alba was reduced to two, and many were found dead with bleeding from external openings of the nostrils, a characteristic sign of anti-coagulant rodenticide poisoning. Monitoring programmes on exposure of anti-coagulant rodenticides in United States, Canada and Europe have shown evidence of extensive contamination of anti-coagulant rodenticides in raptors (e.g. Stone et al., 2003; Thomas et al., 2011; Sanchez-Barbudo et al., 2012). Contamination with anti-coagulant rodenticides is considered to be one of the most detrimental threats to wildlife. Raptor and other predator populations have been reported to decline in numbers when anti-coagulant rodenticides were introduced in farmlands against rodent pests (e.g. Elmeros et al., 2011; Gabriel et al., 2012). Besides the lethal effects, exposure to pollutants can lead to sub-lethal effects such as poor growth performance of nestlings and can even kill the nestlings (Borst and Counotte, 2002; Yoccoz et al., 2009; Thomas et al., 2011). The retention of contaminant in wild owl population can lead to lower reproduction and decreased health status of nestlings (Burger and Gochfeld, 1996; Sheffleld, 1997; Janssens et al., 2003).

The effects of anti-coagulant rodenticides on adult barn owls have been well documented (Erickson and Urban, 2004). However, the sublethal effects of anti-coagulant rodenticides on survival and growth of nestlings of barn owl are largely unexplored. If the larger adults succumb from rodenticide poisoning, the risk to the nestlings would be definitely greater. Studies of bird growth have traditionally focused on changes of body weight (Wilson et al., 1987). However, growth rate of different parts of the morphological features have been used in investigations of nestling growth pattern (Nagarajan et al., 2002; Vigo et al., 2011). The growth rate parameters estimated from such information could be used to determine the sub-lethal effects of anti-coagulant rodenticide secondary poisoning to nestlings of $T$. alba in rat baiting areas in oil palm plantations. Hence, this study was carried out to determine the sub-lethal effects of chlorophacinone and bromadiolone on the survival and growth of barn owl, Tyto alba javanica nestlings in oil palm plantations.

\section{METHODOLOGY}

\section{Study Site and Treatment}

The study was conducted in a mature oil palm plantation in Felda Jengka $24\left(\mathrm{~N}=03^{\circ} 45^{\prime}, \mathrm{E}=\right.$ 102 ${ }^{\circ}$ ), Felda PPPTR (Pusat Penyelidikan Pertanian

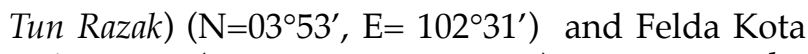
Gelanggi $5\left(\mathrm{~N}=03^{\circ} 57^{\prime}, \mathrm{E}=102^{\circ} 35^{\prime}\right)$, Jerantut in the state of Pahang, Malaysia. Distance between the three sites were approximately 10 to $15 \mathrm{~km}$. The sites were sufficiently far apart to prevent barn owls from hunting across different sites. Forty-two artificial nest boxes (14 nest boxes/area) were selected for this study. The nest boxes were made of highly durable fibreglass (50 width $\times 115 \mathrm{~cm}$ length $\times 61 \mathrm{~cm}$ height). The nest boxes were installed at a height of $7 \mathrm{~m}$ above ground. The boxes were approximately distributed at a density of one box per 15 ha. Thus, each study site was approximately 210 ha giving a total hectarage of 630 ha. Two types of anti-coagulant rodenticides, i.e. chlorophacinone $(0.005 \%$ a.i. $)$ and bromadiolone $(0.005 \%$ a.i.) were applied at Felda PPPTR and Felda Kota Gelanggi 5, respectively. Felda Jengka 24 was kept rodenticide-free as the control plot. Previously, all areas were baited with chlorophacinone in a single application a year. However, Felda Jengka 24 has applied rodenticide baits six months prior to the commencement of the study. Baiting was conducted twice a year during the study period in March and September which coincided with the peak breeding season of T. alba. Each campaign involved two baiting rounds. Baits were placed at the base of the palm at a bait density of one bait per palm.

\section{Sampling Procedure}

A total of 14 nestlings were selected from rodenticide-free, chlorophacinone and bromadiolone treated plots. The selection of nestling in selected nest boxes was limited to the first three siblings in one brood; the subsequent siblings were excluded from the study. This criterion was chosen to minimise the mortality of nestlings due to shortage of food in treated areas as reported by Naim et al. (2010). Application of rodenticide was carried out twice during the breeding season of barn owls.

For identification purpose, each hatched sibling was marked with indelible ink on one of its legs on the first day of its life. At two weeks old, each chick was marked using different coloured ribbons tied to the left leg. Daily observation was conducted on the survival of nestlings. To reduce disturbance at nest, the chicks were measured at three-day intervals starting from just after hatching to Day 52. For monitoring growth rate, the nestling age was recorded as Day 0 upon hatching (Nagarajan et al., 2002). All observations and measurements were carried out in the morning before noon. Some of the nestlings died during the course of the measurement exercise and were excluded for estimation of growth rate parameters. This was to ensure that analysis would accurately describe the growth rate of nestlings in different plots. A total of 16 sampling days were successfully conducted to 
measure nestlings from Day 1 to Day 52 at three-day intervals, i.e. Day 1, 4, 7, 10, 13, 16, 19, 22, 25, 28, 31, 34, 40, 46, 49 and 52. However, no measurements were taken on Day 37 and Day 43 due to logistic problem.

\section{Nestling Growth Metrics}

The measurement of nestlings followed the procedure described by Nagarajan et al. (2002). Growth rates of nestlings were assessed by taking body weight and three different morphological measurements namely culmen length, tarsus length and wing length on a regular basis. Body weight (g) of nestlings was measured using a portable digital weighing scale. The culmen and tarsus were measured using a caliper. The culmen length ( $\mathrm{mm})$ was measured from the tip of the upper mandible to the tip of the bill. Tarsus length ( $\mathrm{mm}$ ) was measured from the tibio-tarsus joint to the distal end to the joint at the base of the middle toe. Wing length $(\mathrm{cm})$ was measured using stainless steel ruler. The wing length was measured from the bend of the folded wing to the tip of the longest primary.

\section{Liver and Residue analysis}

The carcasses found were sent to the laboratory. Autopsies were carried out to determine the cause of death and liver tissues were taken for analysis of residue. A high performance liquid chromatography (HPLC) analysis was conducted at the toxicology laboratory, Department of Plant Protection, Faculty of Agriculture, Universiti Putra Malaysia, Selangor, Malaysia. Analysis of liver samples was based on methods described by Chalermchaikit et al. (1993) and Vudhatala et al. (2010).

\section{Statistical Analysis}

The growth rate of four variables (body weight, culmen length, tarsus length and wing length) in each treatment plot was determined by fitting the growth curve by a logistic equation developed by Ricklefs (1967) and Starck and Ricklefs (1998). The calculation resumed from Day 1 to Day 52 at threeday intervals:

$$
\mathrm{G}=\frac{\mathrm{A}}{1+\exp \left[-\mathrm{K}\left(\mathrm{t}_{\mathrm{w}}-\mathrm{t}_{\mathrm{o}}\right)\right]}
$$

where $G$ is the growth variables at Day $t_{w^{\prime}} A$ is the asymptote of the growth curve, $K$ is the growth rate constant, and $t_{0}$ is the age in days at the point of inflection on the growth curve. The values of logistic growth equations were fitted to the data using the non-linear regression procedure of the Statistical Analysis System (SAS) 9.2 version.

\section{RESULTS AND DISCUSSION}

\section{Survival and Mortality of Selected Nestlings}

A total of 21 nestlings were successfully measured up to Day 52 and percent mortality is shown in Table 1. Rodenticide-free plot showed the highest number of nestlings, i.e. 10 (71.42\%) successfully measured up to Day 52 until fledged. In chlorophacinone plot, six of 14 nestlings $(42.85 \%)$ were successfully measured to fledging. Meanwhile, in bromadiolone plot only five $(35.71 \%)$ nestlings were successfully measured up to Day 52.

During measurements, four nestlings in rodenticide-free area died at the age of less than 14 days before commencement of rodenticide aplication in treated plots. No analysis for residue was carried out from the carcasses as nestlings were too small (less than $200 \mathrm{~g}$ ) to harvest the liver and the internal organs. Carcasses were also in the advanced stage of decomposition that made analysis not practical or impossible. In bromadiolone treated areas, six died before rodenticide application commenced and three succumbed a month after the start of rodenticide application. In the chlorophacinone treated areas, four of eight nestlings died before rodenticide application and four nestlings died during application of rodenticide in the field. Autopsies on these nestling carcasses showed anticoagulant poisoning and massive haemorrhaging in the organs examined.

Residue analysis of nestling carcasses found in the field in all treatment plots are shown in Table 2. In bromadiolone treated plot, nine carcasses were found but only three were suitable for analysis. From the three carcasses, only two samples were detected with residues at $0.33 \mu \mathrm{g} \mathrm{g}^{-1}$ and $0.41 \mu \mathrm{g} \mathrm{g}^{-1}$ wet weight, respectively. In chlorophacinone plot, eight carcasses were found and three were subjected to HPLC analysis. Residues of bromadiolone were each detected at $0.18 \mu \mathrm{g} \mathrm{g}^{-1}, 0.25 \mu \mathrm{g} \mathrm{g}^{-1}$ and $0.17 \mu \mathrm{g} \mathrm{g}^{-1}$. The high residues of bromadiolone and chlorophacinone in the liver samples from the carcasses showed that nestlings in baited areas face high risk of secondary poisoning. If the owl parents bring home rats that had consumed baits, the nestlings would be exposed to secondary poisoning. No analysis was carried out in the rodenticide-free area as there were no carcasses collected for analysis.

\section{Growth Performances of Barn Owl Nestlings}

Body weight. All logistic curves of nestlings' mean growth follows a sigmoidal curve. The logistic curve of body weight growth in rodenticide-free area reach asymptote (A) between Day 40 and Day 42. This is similar for nestlings in bromadiolone treated area and chlorophacinone treated area. However, body weight growth in rodenticide-free area reached a 
TABLE 1. NUMBER OF SAMPLES AND SUCCESS TO FLEDGE

\begin{tabular}{lcccc}
\hline Treatment & $\begin{array}{c}\text { Number of } \\
\text { samples }\end{array}$ & $\begin{array}{c}\text { Died during } \\
\text { measurement }\end{array}$ & $\begin{array}{c}\text { Fledging } \\
\text { success }\end{array}$ & $\begin{array}{c}\text { Nestling } \\
\text { survived }\end{array}$ \\
\hline Rodenticide-free & 14 & 4 & 28.6 & 10 \\
Bromadiolone & 14 & 9 & 64.3 & 5 \\
Chorophacinone & 14 & 8 & 57.1 & 6 \\
\hline
\end{tabular}

TABLE 2. DEATH OF NESTLING BASED ON AGE GROUP AND RESIDUE OF ANTI-COAGULANTS IN LIVER ( $\mu \mathrm{g} \mathrm{g}^{-1}$ wet weight)

\begin{tabular}{lccc}
\hline Treatment & $\begin{array}{c}\text { Age group of } \\
\text { nestling (days) }\end{array}$ & Mortality & $\begin{array}{c}\text { Mean residue } \pm \text { s.e } \\
\left(\mu \mathbf{g ~ g}^{-1}\right)\end{array}$ \\
\hline \multirow{2}{*}{ Rodenticide-free } & $<30$ & 4 & na \\
& $41-40$ & 0 & - \\
Bromadiolone & $41-50$ & 0 & - \\
& $31-40$ & 6 & na \\
& $41-50$ & 2 & $0.33 \pm 0.00(\mathrm{~d}=1, \mathrm{nd}=1)$ \\
Chlorophacinone & $<30$ & 1 & $0.41 \pm 0.00$ \\
& $31-40$ & 5 & na \\
& $41-50$ & 1 & $0.18 \pm 0.00$ \\
& 2 & $0.21 \pm 0.10(\mathrm{~d}=2, \mathrm{nd}=0)$ \\
\hline
\end{tabular}

Note: na - analysis was not conducted, d - detected, nd - not detected.

higher asymptote value $(579.9 \pm 10.7 \mathrm{~g})$ compared with bromadiolone and chlorophacinone treated plots of $544.4 \pm 7.05 \mathrm{~g}$ and $565.0 \pm 8.44 \mathrm{~g}$, respectively (Figure 1).

The highest increase in body weight (inflection value, ti) in the rodenticide-free plot was recorded on Day $19.20 \pm 0.32$, while for bromadiolone and chlorophacinone at Day $18.12 \pm 0.33$ and $18.34 \pm$ 0.28 , respectively. The difference in the asymptote and inflection values in turn depends on the growth constant value. Nestlings in the rodenticide-free plot shows the highest growth constants, i.e. 0.1559 per day followed by chlorophacinone and bromadiolone at $0.1495 \mathrm{day}^{-1}$ and 0.1472 per day, respectively. These clearly show that nestlings in rodenticides treated plots had poor body weight growth as compared to rodenticide-free plot.

The constant growth rate in body weight of nestling in rodenticide-free plot was similar as previously reported by Lenton (1984), i.e. $\mathrm{K}=0.150$ 0.162 per day, and with African subspecies T. alba affinis ( $\mathrm{K}=0.151)$ (Wilson et al., 1987), as the peak in body weight occurred between Day 42 and Day 49. However, the growth rate was slightly higher as compared to Indian barn owl, T. alba stertens (K $=0.132$ per day) (Nagarajan et al., 2002) and slightly lower compared to European barn owl subspecies T. alba alba ( $\mathrm{K}=0.177$ per day) (Durant and Handrich, 1998). Meanwhile, the constant growth rate in body weight of nestling in rodenticide treated plots was similar to that reported by Naim et al. (2010), i.e.
$\mathrm{K}=0.146-0.147$ per day. They conducted a study in immature oil palm plantation and showed that brodifacoum and warfarin decreased body weight growth of nestlings up to $20 \%$ and $10 \%$, respectively. Teratogenic signs in a few nestlings as a morphological evidence was used as evidence to support claims of secondary poisoning.

Lander et al. (1991) conducted a captive study on 18 nestlings at the age of one month old. The nestlings lost weight after consuming poisoned mice daily over a period of one month. Nestlings in brodifacoum treatment lost up to $25 \%$ of their initial weight. Similar study was conducted by Radvanyi et al. (1988) using juvenile of captive kestrel Falco sparverius. They found chlorophacinone reduced weight of kestrel juveniles reduced in weight by up to $22 \%$ of the initial weight. In contrast, control birds increased $5 \mathrm{~g}$ or $4 \%$ of their initial weight over an observation period of 21 days. The rodenticide has an overall effect on the growth of the nestlings up to the adult stage. Both studies had shown secondary poisoning adverse effects on nestling growth even when food is sufficient.

Tarsus and culmen length. Bird growth rates are usually derived from non-linear relationships between age and body weight, but this procedure could have limitation and not really precise as the body weight is fully dependent on the diet of barn owls in the respective days of measurement. Besides, decrease of nestling body weight could be 
a)

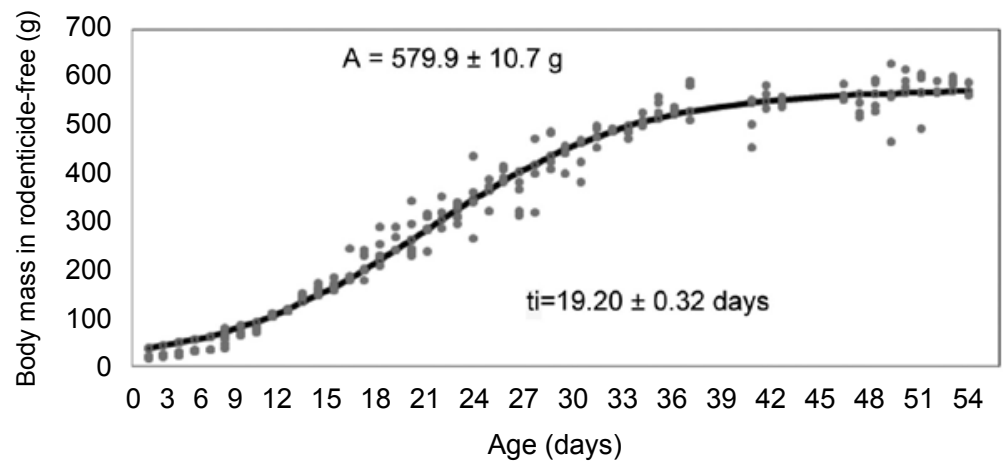

b)

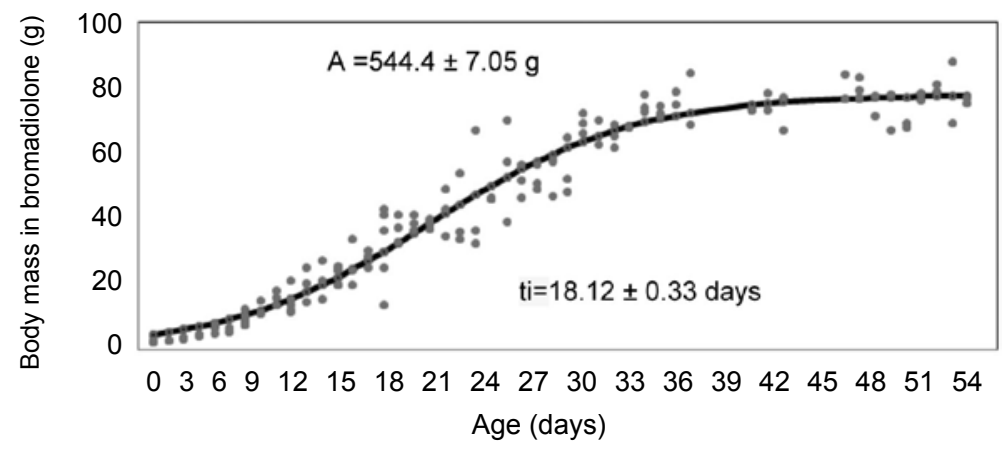

c)

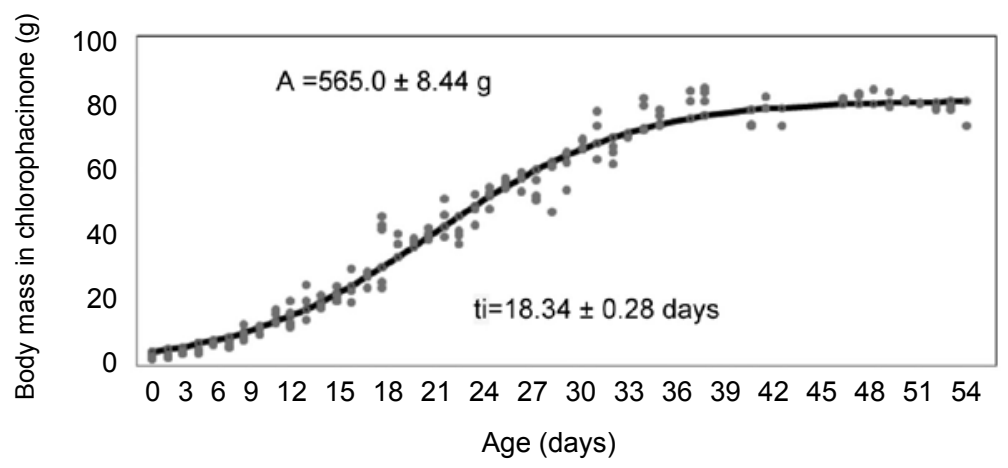

Figure 1. Logistic growth curves of the changes in body weight of nestlings in rodenticide-free (a), bromadiolone (b) and chlorophacinone (c) treated plots. ' $A$ ' is asymptote and ti the inflection point.

attributed to direct or indirect toxicity due to food shortage (Eeva et al., 1997). Hence, chick growth rates were estimated by measurement of morphological features associated with bone structure (e.g. tarsus and culmen). Tarsus and culmen length may grow normally even with food restrictions (Lepczyk and Karasov, 2000). Thus, these morphological measurements can serve as a good parameter to indicate sub-lethal effects through secondary poisoning on nestlings of barn owls. The logistic curve for growth of tarsus is presented in Figure 2. Nestling's tarsus length grew gradually in the first week and then increasing rapidly to Day 30 and finally slowing down until the nestling fledged. In rodenticide-free plots, nestling's tarsus growth reached asymptote earlier at around 33 to 36 days after nestlings reaching asymptote at $88.30 \pm 0.29$ $\mathrm{mm}$. Tarsus length of nestlings in chlorophacinone and bromadiolone treated plots reached asymptote at $87.90 \pm 0.41 \mathrm{~mm}$ between Day 36 to 39 and 87.63 $\pm 1.50 \mathrm{~mm}$ between Day 39 to Day 42 , respectively.

The difference in asymptote value and the day when asymptotes were reached among treatments reflected the ability and the timing of nestlings to reach fledging age. The difference in the asymptote value in turn depends on the growth constant value. Nestlings in the rodenticide-free plot shows the highest growth constants, i.e. 0.1520 per day followed by chlorophacinone and bromadiolone at 0.1384 per day and 0.1285 per day, respectively. Similarly, the inflection points which refer to the highest increase in nestling tarsus length differ among treatments. Rodenticide-free plot shows the highest at Day $14.68 \pm 0.05$ and followed by bromadiolone and chlorophacinone at $13.01 \pm 1.01$ and Day $13.42 \pm 0.16$, respectively. These findings 
a)

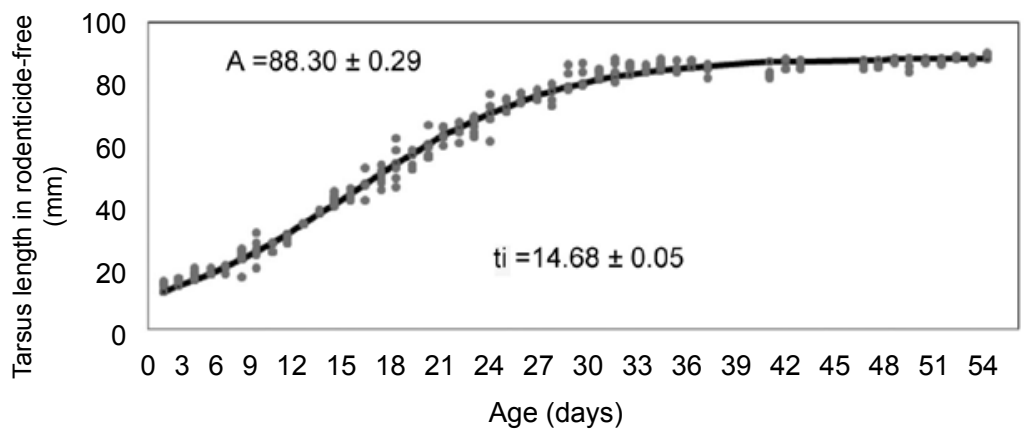

b)

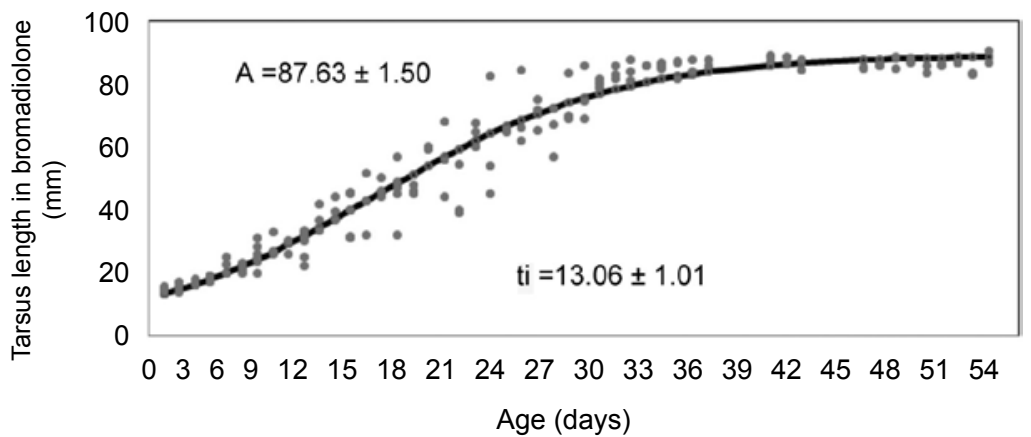

c)

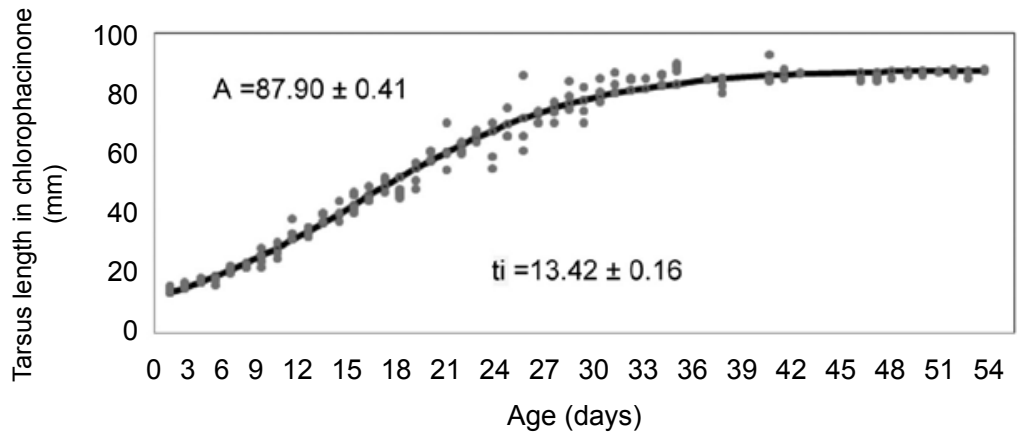

Figure 2. Logistic growth curves of the changes in tarsus length of barn owl nestlings in rodenticide-free (a), bromadiolone (b) and chlorophacinone (c) plot; ' $A$ ' is asymptote and ti the inflection point.

are similar to those reported by researchers who studied the growth of barn owl nestlings in India. Nagarajan et al. (2002) reported the tarsus length of nestlings of Indian barn owl grew in sigmoidal pattern. They reported that in natural environment the tarsus length reached asymptote at $81 \mathrm{~mm}$ with growth constant at 0.0095 per day and the highest increase in tarsus measurement was detected at Day 17.3.

Similarly, patterns in culmen growth in all treatments were similar to the other parameters, i.e. sigmoidal curve (Figure 3). The asymptote value of nestlings in rodenticide-free area was slightly higher at $22.98 \mathrm{~mm}$ compared to bromadiolone and chlorophacinone treated plots, at $22.20 \mathrm{~mm}$, and $22.18 \mathrm{~mm}$, respectively. The inflection point (ti) indicates the highest increase in culmen length on Day 10.55 \pm 0.17 , Day $10.41 \pm 0.22$ and $10.59 \pm 0.15$ in nestlings from rodenticide-free plot, bromadiolone and chlorophacinone treated plots, respectively. Similarly, the growth constant in rodenticidefree area was 0.1020 per day higher than both in bromadiolone and chlorophacinone treated areas, i.e. 0.957 and 0.967 per day respectively.

The growth constant value in rodenticides treated plots shows that culmen growth is slower compared to rodenticide-free plot. Faster growth of tarsus and culmen is crucial for nestling to be independent and able to hunt for prey. The poor growth of tarsus and culmen in both treated plots cause delay in reaching maturity and consequently lead to delayed fledging. Rapid growth of the tarsus and culmen is considered by Nagarajan et al. (2002) as an important morphological growth in preparation for post-fledging foraging activities, such as collecting and handling of food items. Thus, 
a)

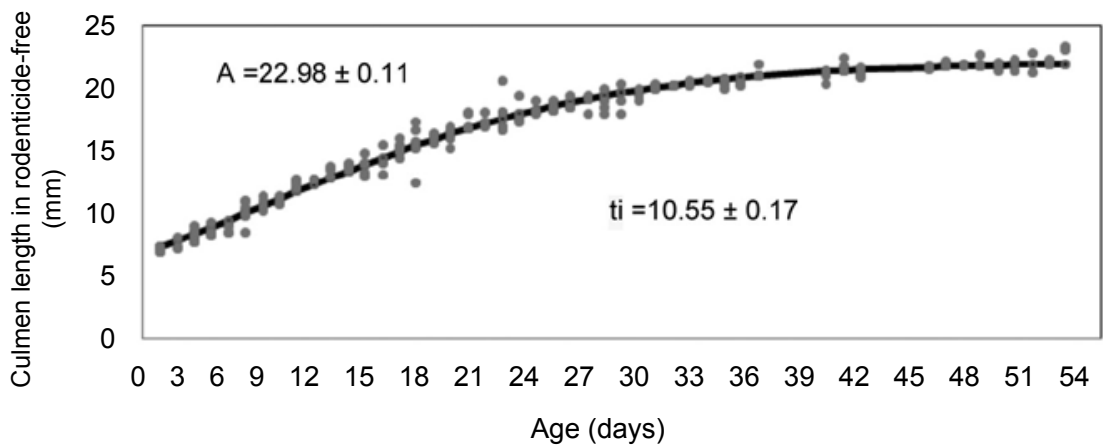

b)

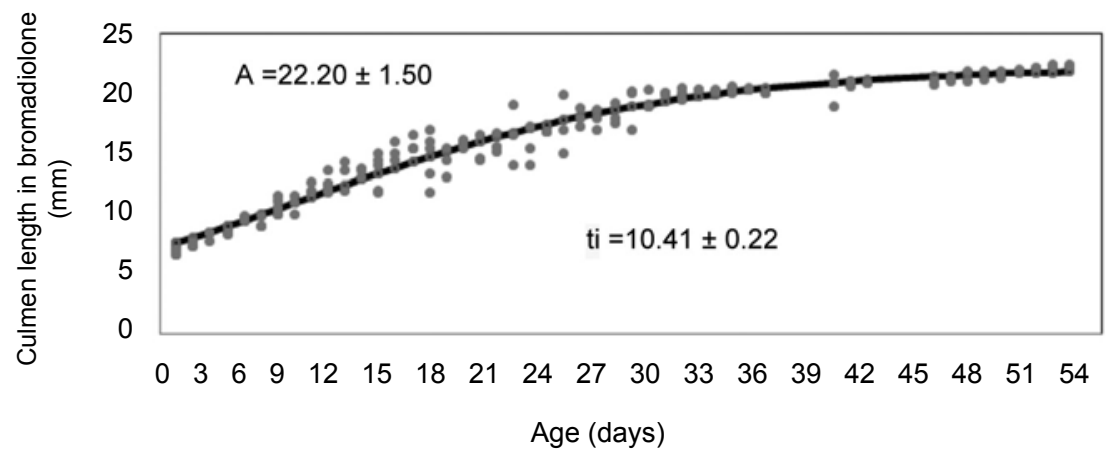

c)

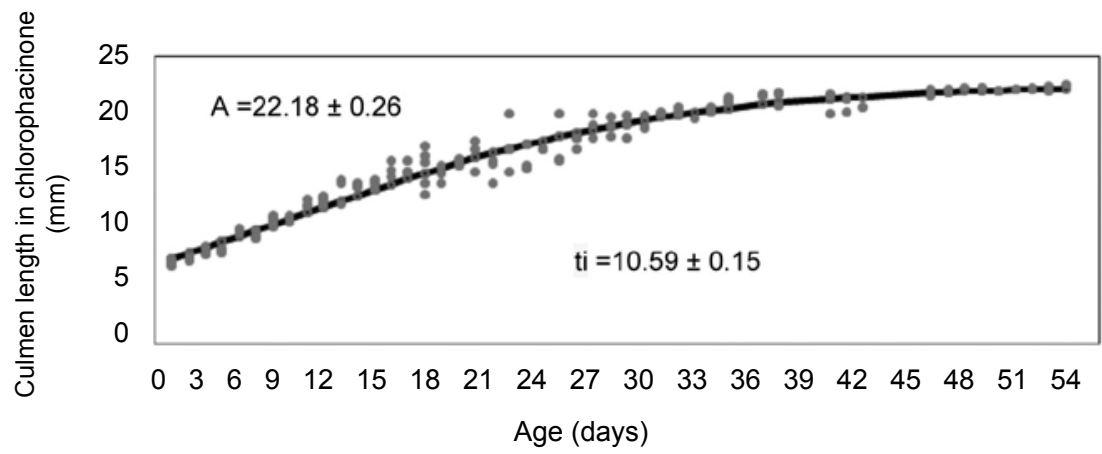

Figure 3. Logistic growth curves of the changes in culmen length of nestling barn owls in rodenticide-free (a), bromadiolone (b) and chlorophacinone (c) plot. ' $A$ ' is asymptote and ti the inflection point.

rapid tarsus and culmen growth rates are useful parameters to study the health status of nestling and effects of secondary poisoning.

Many studies have shown that some birds have shorter anatomical parts particularly those involved with bone formation such as tarsus and culmen, if they are exposed to pesticides or if they live in polluted areas (Hoffman et al., 1985; Dauwe et al., 2006; Albert et al., 2008). The screech owls (Otus asio) administered with fluoride at $40 \mu \mathrm{g} \mathrm{g}^{-1}$ resulted in significantly smaller eggs and shorter tarsus length (Hoffman et al., 1985). Besides that, Janssens et al. (2003) reported the nestlings of the great tit (Parus major) exposed to large amounts of heavy metals showed a decrease in tarsus length growth. While Nam and Lee (2006) reported the length of tarsus and culmen of nestlings of feral pigeons (Columba livia) from polluted areas with heavy metals $(\mathrm{Cd})$ were shorter than those from less polluted areas.

Wing length. Wing length was reported to grow normally even with food restrictions (Best, 1977; Lepczyk and Karasov, 2000). Wing growth in nestlings involves complex development of bone growth and structure of feathers. Thus, it can serve as a good parameter to indicate sub-lethal effects through secondary poisoning on nestlings of barn owls. The growth curves of wing length in all treatments were sigmoidal (s-shaped) (Figure 4). Asymptotes estimated were $28.70 \pm 0.14 \mathrm{~cm}, 26.02$ $\pm 0.22 \mathrm{~cm}$ and $26.30 \pm 0.23 \mathrm{~cm}$ in rodenticide-free, bromadiolone and chlorophacinone treated plots, respectively. The growth constant, range from 0.0962 , 0.0855 and $0.0802 \mathrm{~cm}$ per day in rodenticide-free, 
a)

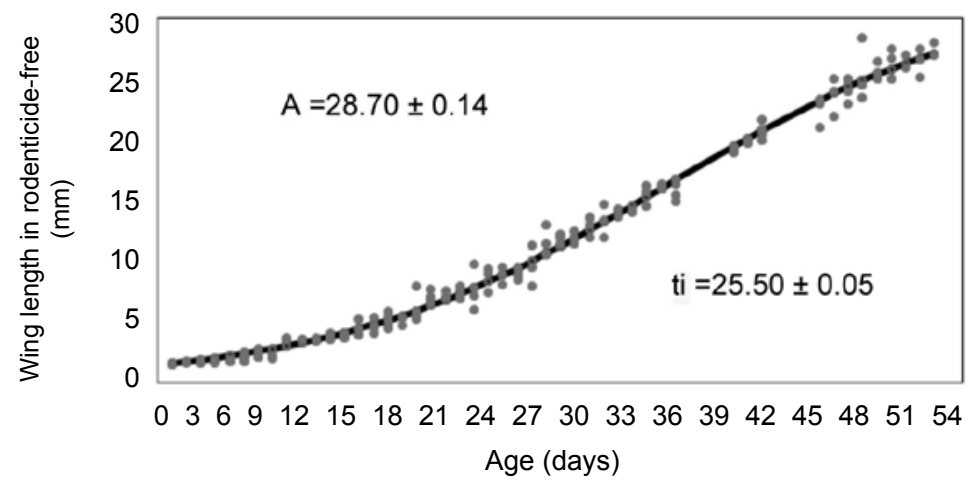

b)

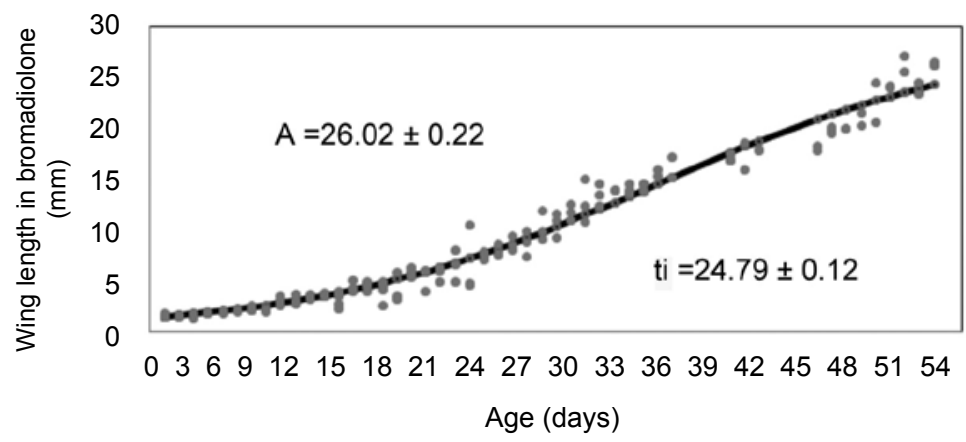

c)

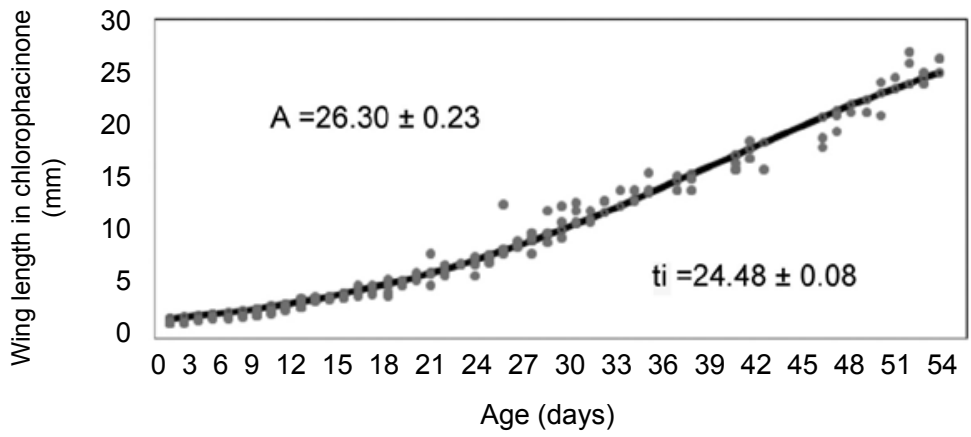

Figure 4. Logistic growth curves of the changes in wing length of nestling barn owls in rodenticide-free (a), bromadiolone (b) and chlorophacinone (c) plot. ' $A$ ' is asymptote and ti the inflection point.

bromadiolone and chlorophacinone treated plots, respectively. The inflection point differed from one treatment to another, ranging from Day 25.50 \pm 0.05 , Day $24.79 \pm 0.12$ and Day $24.48 \pm 0.08$ in rodenticidefree, bromadiolone and chlorophacinone treated plots, respectively.

Naim et al. (2010) who worked with the same subspecies of barn owl in a different environment reported wing length of nestling reached asymptote at $26.28 \mathrm{~g}$ in control plot, higher by $4.13 \mathrm{~g}$ compared to rodenticides treated plots. Wings in treated plots were shorter by $15.26 \%$ compared to nestlings in rodenticide-free area. The lower asymptote value shows poor growth of wing of nestlings in rodenticides treated plots. The poor wing growth of nestlings in the present study has extended the time for nestlings to reach fledging age. All nestlings survived to the last day of measurements, i.e. Day
52. Nestlings raised in rodenticide-free area fledged successfully upon release into the field but those from treated areas needed another one or two weeks before they could take to flight.

Dauwe et al. (2006) found that the wings of great tits (Parus majus) were shorter at pollution site as compared to reference areas. Similarly, Talloen et al. (2008) reported nestlings of great tits living in elevated levels of pollutants have shorter wings than birds living under natural levels of contaminants. Albert et al. (2008) exposed passerine birds of zebra finch (Taeniopygia guttata) nestlings to arsenic-based pesticides (monosodium methaersonate) for 20 days through oral administration. They found that survived nestlings were reduced and surviving nestling showed reduced growth and decreased tarsus and wings length upon fledging. Eeva and Lehikoinen (1996) reported growth abnormalities of wing of T. guttata in polluted 
areas with heavy metals from industrial chemicals, about $27 \%$ of the broods contained one or more nestlings with visible defects in their limbs (impaired leg or wing) whereas in reference areas almost none were affected. Although some of the affected nestlings died, some crippled nestlings achieved fledging size. However, the latter failed to leave their nest and eventually starved to death.

\section{CONCLUSION}

Rodenticides did not only kill nestlings outright but can also induce sublethal effects in the form of compromised or stunted growth. High mortality of nestlings in rodenticide applied areas with the active ingredients detected in the liver tissues of carcasses collected reflected the great risk of secondary poisoning. Nestlings in rodenticide-free area showed a greater body weight, larger measurements of tarsus, culmen and wings compared to bromadiolone and chlorophacinone treated plots. Nestlings in the latter did not only face indirect risk of food shortage due to the high efficacy of the rodenticides, but also the direct risk of secondary poisoning from ingesting rats that have taken rodenticide baits. Therefore, rodenticide application should be carried out during the off breeding season (April to May). As much as possible, baiting should be avoided during breeding season.

\section{REFERENCES}

ALBERT, C; WILLIAMS, T D; MORRISSEY, C A; LAI, V W M; CULLEN, W C and ELLIOTT, J E (2008). Tissue uptake, mortality, and sublethal effects of monomethylarsonic acid [MMA(V)] in nestling Zebra Finches (Taeniopygia guttata). J. Toxicology and Environmental Health, 71: 353-360.

BEST, L B (1977). Nestling biology of the field sparrow. Auk, 94: 308-319.

BORST, G H A and COUNOTTE, G H M (2002). Shortfall using anticoagulant rodenticide. J. Zoo and Wildlife Medicine, 33(1): 85.

BURGER, J and GOCHFELD, M (1996). Heavy metal and selenium levels in Franklin's gulls (Larus pipixcan) parents and their eggs. Arch Environment Contamination Toxicology, 30: 487-491.

CHALERMCHAIKIT, T; FELICE, L J and MURPHY, M J (1993). Simultaneous determination of eight anticoagulant rodenticides in blood serum and liver. J. Analytical Toxicology, 17: 56-61.
DAUWE, T; JANSSENS, E and EENS, M (2006). Effects of heavy metal exposure on the condition and health of adult great tits (Parus major). Environment Pollution, 140: 71-78.

DUCKETT, D E (1984). Barn owls (Tyto alba) and the 'second generation' rat-baits utilised in oil palm plantations in Peninsular Malaysia. The Planters, 60: 3-11.

DURANT, J M and HANDRICH, Y (1998). Growth and food requirement flexibility in captive chicks of the european barn owl (Tyto alba). J. Zoology, 245 (02):137-145.

EEVA, T and LEHIKOINEN, E (1996). Growth and mortality of nestling great tits (Parus major) and pied flycatchers (Ficedula hypoleuca) in a heavy polluted metal pollution gradient. Oecologia, 108: 631-639.

EEVA, T; LEHIKOINEN, E and POHJALAINEN, T (1997). Pollution-related variation in food supply and breeding success in two hole-nestling passerines. Ecology, 78: 1120-1131.

ELMEROS, M; CHRISTENSEN, T K and LASSEN, P (2011). Concentrations of anticoagulant rodenticides in stoats (Mustelaermine) and weasels (Mustela nivalis) from Denmark. Science of the Total Environment, 409: 2373-2378.

ERICKSON, W and URBAN, D (2004). Potential Risks of Nine Rodenticides to Birds and Nontarget Mammals: A Comparative Approach. Office of Pesticides Programs Environmental Fate and Effects Division, United States Environmental Protection Agency, Washington. http:/ / www.fluoridealert. org / pesticides / EPA-HQ-OPP-2006-0955-0005.pdf, $20 \mathrm{pp}$.

GABRIEL, M W; WOODS, L W; POPPENGA, R; SWEITZER, R A and THOMPSON, C (2012). Anticoagulant rodenticides on our public and community lands: spatial distribution of exposure and poisoning of a rare forest carnivore. http: / / www. plosone.org/article/info $\% 3 \mathrm{Adoi} \% 2 \mathrm{~F} 10.1371 \% 2 \mathrm{Fj}$

HOFFMAN, D J; PATTEE, O H and WIEMEYER, S N (1985). Effects of fluoride on screech owl reproduction: teratological evaluation growth, and blood chemistry in hatchings. Toxicity letters, 26: 1924.

JANSSENS, E; TOM DAUWE, T; PINXTEN, R; BERVOET, L; BLUST, R and EENS, M (2003). Effects of heavy metal exposure on the condition and health of nestlings of the great tit (Parus major), a small 
songbird species. Environmental Pollution, 126: 267274.

LANDER, E; LOPEZ, J; DIAZ, C and COLMENARES, M (1991). Population biology of the barn owl (Tyto alba) in Guarico State, Venezuela. Birds of Prey Bulletin, 4: 167-173.

LENTON, G M (1984). The feeding and breeding ecology of barn owl (Tyto alba) in Peninsular Malaysia. Ibis, 126: 551-575.

LEPCZYK, C A and KARASOV, W H (2000). Effect of ephemeral food restriction on growth of house sparrows. Auk, 117: 164-174.

NAGARAJAN, R; THIYAGESAN, K; NATARAJAN, $R$ and KANAKASAI, $R$ (2002). Patterns of growth in nestling indian barn owl. The Condor, 104: 885-890.

NAIM, M; HAFIDZI, M N; KASSIM, A and ABU, J (2010). Growth performance of nestling barn owls, Tyto alba javanica in rat baiting area in Malaysia. ARPN J. Agricultural and Biological Science, 5(6): 1-13.

NAIM, M; UMAR, U J and HAFIDZI, M N (2012). The ranging behaviour of Tyto alba in oil palm under baiting with anticoagulant rodenticides, warfarin and brodifacoum and a biorodenticide Sarcocystis singaporensis. Pertanika J. Tropical Agricultural Science, 35 (2): 209-221.

NAM, D H and LEE, D P (2006). Reproductive effects of heavy metal accumulation on breeding feral pigeons, Columba livia. Science Total Enviroment, 366: 682-687.

RADVANYI, A; WEAVER, P; MASSARI, C; BIRDT, D and BROUGHTON, E (1988). Effects of chlorophacinone on captive kestrels. Bulletin Environment Contamination Toxicology, 41: 441-448.

RICKLEFS, R E (1967). A graphical method of fitting equations to growth curves. Ecology, 48: 978-983.

SANCHEZ-BARBUDO, I S; CAMARERO, P R and MATEO, R (2012). Primary and secondary poisoning by anticoagulant rodenticides of non-target animals in Spain. Science of the Total Environment, 420: 280288
SHEFFIELD, S (1997). Owls as biomonitors of environment contamination. $2^{\text {nd }}$ Owl Symposium. Manitoba, Canada. p. 383-398.

STARK, J M and RICKLEFS, R E (1998). Avian Growth and Development. Oxford University Press, New York, USA.

STONE, W B; OKONIEWSKI, J C and STEDELIN, J R (2003). Anticoagulant rodenticides and raptors: recent findings from New York, 1998-2001. Bulletin Environmental Contamination Toxicology, 70: 34-40.

TALLOEN, W; LENS, L; VAN DONGEN, $S$ and MATHYSEN, E (2008). Feather development under environment stress lead exposure effects on growth patterns in great tits (Parus major). Bird Study, 55: $108-117$

THOMAS, $\mathrm{P}$ J; MINEAU, $\mathrm{P}$; SHORE, $\mathrm{R}$ F; CHAMPOUX, L; MARTIN, P A; WILSON, L K; FITZGERALD, G and ELLIOTT, J E (2011). Second generation anticoagulant rodenticides in predatory birds: probabilistic characterisation of toxic liver concentrations and implications for predatory bird populations in Canada. Environment International, 37: 914-920.

VIGO, G; WILLIAMS, $\mathrm{M}$ and BRIGHTSMITH, D J (2011). Growth of scarlet macaw (Ara Macao) chicks in southern Peru. Ornitologia Neotropical, 22: 143-153.

VUDATHALA, D; CUMMINGS, M and MURPHY, L (2010). Analysis of multiple anticoagulant rodenticides in animal blood and liver tissue using principles of QuEChERS method. J. Analytical Toxicology, 34: 273-279.

WILSON, R T; WOLSON, M P and DURKIN, J W (1987). Growth of nestling barn owls Tyto alba in central Mali. Ibis, 129: 305-318.

WOOD, B J and CHUNG, G F (2003). A critical review of the development of rat control in Malaysian agriculture since the 1960's. Crop Protection, 22: 445461.

YOCCOZ, N G; BUSTNES, J O; BANGJORD, G and SKAARE, J U (2009). Reproduction and survival of tawny owls in relation to persistent organic pollutants. Environment International, 35: 107-112. 